\title{
FEATURES OF MARKETING ACTIVITIES OF THE FOOTBALL CLUB “NIZHNY NOVGOROD”
}

\author{
Ekaterina Bulanova, Marina Platonova, Olga Rokunova \\ National Research Lobachevsky State University of Nizhny Novgorod, Russia
}

\begin{abstract}
The relevance of the research topic is due to the fact that marketing in sports is an effective component of sports management, just as it is in other areas of management. Sports marketing has its own specific features based on the characteristics of a particular sport, and this article deals with football marketing. The purpose of this article is to reflect the results of the study of a sports club's marketing activities. The object of the study is the regional football club "Nizhny Novgorod"(Russia). The main objectives of the study are to identify the factors that attract the fans' interest to the football club, to attending matches and purchasing club merchandise. Based on a survey of Nizhny Novgorod residents, a study of football fans' needs in the region was carried out and the target audience of the FC "Nizhny Novgorod" was determined. The results of the survey show that the fans are poorly motivated to attend football matches with the participation of this club. The potential of modern promotion methods such as social media marketing (SMM) is used insufficiently. There is a need to make a more active impact on football consumers in the region, to intensify the work with the fans of the club, to improve the quality and design of the club's merchandise. As a result of our research, a series of measures have been developed aiming to involve fans in the club's life, both on match days and between matches. These measures include: promoting season ticket sales, more effective use of the home stadium on match days, active work to attract families with children, organising family leisure at the stadium, stadium tours, activities outside the stadium - weekend events in the city's parks. The value of the research findings presented in the article lies in identifying the need to create the conditions for a football feast based on football marketing methods, aiming to attract fans to the club.
\end{abstract}

Keywords: fan, football club, football marketing, marketing, sports club activities, strategy.

\section{Introduction}

Nowadays, football is the most spectacular sport and this is the reason why it attracts so many sponsors. There is a lot of competition in the world of football, and teams that are just starting to gain in popularity are in 
a difficult position. In the Nizhny Novgorod region, our team's situation deteriorates every year and the number of people interested in the team's success, those who buy its merchandise and attend matches, is decreasing. The team has virtually no fans and is far from ranking high in Russia.

The interest in studying the features of marketing in sports is presented in the textbook by Obozhina (2017), as well as in a scientific article by Bagdatovich et al. (2017). In the textbook of Myakonkov et al. (2020), the material on the industry specifics of developing a marketing strategy in the field of sports is described in detail. The domestic and foreign experience of forming models of marketing productivity and systems for evaluating the effectiveness of sports marketing is widely covered in the textbook of Oiner (2021). Aspects of the development and promotion of a sports product, features of communications in sports, the secrets of effective sponsorship and the creation of bright sports brands, as well as approaches to managing sports products in a volatile and uncertain economic environment are described in the textbook edited by Beech and Chadwick (2010). Prokhorenkova (2017) describes the features of the non-commercial sphere of sports marketing. In a scientific article, Samatov (2020) describes a model of future physical education teachers for activities in the field of sports marketing. Tarighi and Hamidi (2017) identify factors that influence the development of marketing opportunities for student sports.

The study of the role of marketing in football was reflected in a series of books by Kopyshov, who worked in all Russian football leagues. In particular, he identifies the main groups of consumers of a football product (Kopyshov, 2013) and describes how the club should interact with them. Kopyshov made a significant contribution to the development of measures to improve the effectiveness of marketing activities of football clubs in Russia and reflected them in his textbook "Football marketing for the Second League" offering an effective model for the development of the commercial service of a football club (Kopyshov, 2015, pp. 22-26).

The football club "Nizhny Novgorod" which is the object of the study, has not been considered in the works of contemporary authors, as it was formed only in 2015. Its first name was "Volga-Olimpiets". The colours were white and blue. In 2016, due to the reorganisation of the non-profit partnership FC "Volga-Olimpiets" into an autonomous non-profit organisation "Football Club "Olimpiets" FC "Volga-Olimpiets" was renamed to FC "Olimpiets" on 3 June 2016. Having changed the name, the team continued to rely on Nizhny Novgorod football players. Thus, Anton Khazov joined the ranks of "Olimpiets" Nikita Nikolaev and Dmitry Polyanin, who had been playing for Nizhny Novgorod clubs since 2007, transferred to FC "Olimpiets" from FC "Volga". In the summer of 2018, it was decided to change the name of the team. FC "Olimpiets" sent a request to the National 
Football League for renaming FC "Olimpiets" to FC "Nizhny Novgorod". The Nizhny Novgorod stadium that was built for the 2018 FIFA World Cup has been the team's home stadium since 2018 and has high potential as a modern sports infrastructure facility in the city and the Nizhny Novgorod region. Its maximum capacity is 45,000 people. The average attendance of the stadium in 2019 was 10,000. In June 2019, Nizhny Novgorod Stadium was transferred from federal ownership to regional ownership. Nizhny Novgorod Region Governor Gleb Nikitin approved a business plan for the operations of the Nizhny Novgorod Stadium. Currently it is managed by the Directorate for Sports and Entertainment Events, a state-owned entity of the Nizhny Novgorod region. According to the official website Government of the Nizhny Novgorod region (2019, January 15), the emphasis is placed on the sports use of the facility, but other uses are also envisaged, including recreation and leisure.

\section{Research method}

The study was focused on the audience of the football club "Nizhny Novgorod". The practice of football marketing shows that there are far more demotivational than motivational factors in Russian football at the moment. This suggests that, firstly, the psychology of Russian football consumers has not been fully studied, and there is a lot of room for research ahead. Secondly, the motivational factors already in place are very poorly communicated to the potential visitors of football matches. Apparently, the stereotype that football is just a sport and nothing more is still strong.

The factors that contribute to attending football matches at the stadium include: joy (one can have fun and relax, negative life emotions go away when a person is watching a match); communication (a feeling of unity with people close in spirit); family (an opportunity to spend time with one's family and watch football at the same time); tonus (a FC "Nizhny Novgorod" match is a whole complex of leisure activities aimed at restoring well-being and performance of a healthy but fatigued person). It is these factors that need to be cultivated among potential match fan. Thus, when building a strategy to attract visitors to football matches, it is necessary to offer more than just a beautiful football game. Everything should be done to ensure that the city's residents who attend a football match could satisfy their need to communicate with their loved ones, to relax, to have fun, to enjoy an open-air event, to release the negative emotions accumulated during the week. Subsequently, meeting these needs would provide the most stable income for the football club.

In order to best describe the target audience of the club and to identify the needs of a football fan, we conducted a survey among the residents of 
Nizhny Novgorod. 300 people were interviewed. The survey was conducted among friends and through social networks. Among those surveyed, 53\% were women and $47 \%$ were men. The average age of more than $50 \%$ of respondents was between 18 and 29 years, 29\% of them were 35 years old or older. Only $24 \%$ of those surveyed had children. In terms of their social status, those surveyed were students and professionals. Almost 30\% of those surveyed had an average income of 30,000-50,000 roubles (340570 euros). Only $16.3 \%$ of those interviewed had a fair income of 50,000 roubles (570 euros) and more. Only 9\% of respondents were not at all interested in sports. The most popular sports, which residents of Nizhny Novgorod are interested in, are hockey and football. Of these two sports, respondents believe that hockey is much better developed in the city than football. The survey also revealed that $89 \%$ of respondents are aware of the existence of the football club "Nizhny Novgorod". Only 3.5\% of respondents go to every match. However, almost half of those surveyed have never attended a game of - FC "Nizhny Novgorod". 23.5\% of respondents attended a match once, and $23.5 \%$ go to a football match occasionally. This shows that there is no incentive for fans to attend matches. More than half of the people who attend the matches go there with their friends, those who go there with their family rank second in terms of attendance. For most fans, the results of the team are satisfactory, but a significant proportion of those surveyed answered that they were not satisfied with the team's performance.

The most effective method of spreading information about the football club is 'word of mouth'. The second most effective dissemination channel is television, followed by social media and then outdoor advertising. This shows that distribution channels need to be carefully designed (Beech \& Chadwick, 2010), and active work with fans in social media is required (Abrosimova \& Kulikova, 2020, pp. 11-12). The club has its pages on the most popular social networks. Activity data as of October 2020 are as follows: VKontakte (russian social network) community - 35.8 thousand followers, Instagram - 12.4 thousand followers; Twitter - 1.3 thousand readers; YouTube -3.28 thousand followers. Turning to price incentives, we asked how much people were able and willing to pay for the tickets for the matches. It turned out that people were willing to give money for good seats in the centre, which cost from 350 roubles, but are not prepared to spend money on season tickets. The price policy for match tickets suits most fans, and they are ready to pay their money once or twice, but only $4 \%$ of respondents are ready to become a part of the team and buy season tickets. Only 9\% of respondents said 'yes' when asked about buying merchandise of FC "Nizhny Novgorod". This means that over $90 \%$ of respondents are not satisfied with the prices, quality and design, as well 
as the ability to buy merchandise at any convenient time. Active engagement with fans is an important incentive to attend matches (Lychagina \& Angelova, 2019).

It was found from the survey that in general the clubss work with its fans before the match, during the match, at half-time break and on the rest of the days is satisfactory. Each of these points has even received the highest ratings for this work, except for the "rest of the days" point. This means that the fans are not satisfied with their interaction with the club, and there is no close fan-team interaction at all times. Based on the survey, our fans want to see the following: friendly staff $-63 \%$; gifts from sponsors $54 \%$; a variety of catering facilities $-46 \%$; comfortable conditions for moving around the stadium (escalators, lifts) - 44\%; autograph signing sessions with the players $-43 \%$; places for playing with children $-35 \%$; master classes/show programmes $-31 \%$; victory fireworks $-30 \%$. The survey data help to identify what the club's home stadium lacks in terms of fan comfort and to propose the introduction of the most important elements (Yesin, 2015; Shteblov, 2015).

\section{Recommendations}

The survey has revealed that the club barely carried out any active work with fans outside the stadium. The survey has suggested some activities that could be carried out on days when there are no matches.

1. Events outside the stadium. This is achieved by running promotion events and having feedback between club representatives, players and potential football consumers. The football club conducts such promotions at Maximilian Bar, but this bar is not well suited to the club's family target audience. It is possible to hold a one-day weekend "island" event of FC "Nizhny Novgorod" in the city's parks. During this event, children will be able to play with FC "Nizhny Novgorod" players, and their parents will get to know the club face to face.

2. Stadium tours. Such events will bring the fans closer to the team, and people who have never attended a FC "Nizhny Novgorod" football match will want to see how the team plays at the stadium.

3. Another important element in establishing a close fan-team bond by means of season tickets and the privileges that fans will get when buying them. The survey has revealed that people do not buy season tickets of FC "Nizhny Novgorod" for one reason or another. Therefore, an important line of marketing activities is to stimulate season ticket sales. 


\section{Discussion}

Football has long been more than just a sporting game. It is no secret that almost any sport is a business.

Having identified, based on the survey results, the needs of the target audience, you can competently develop a strategy for actively working with them. Any fan would like to be part of the team, and not only on match days. In order to achieve this, a range of activities are designed to involve the fans in the clubss life, both on match days and in their spare time. The fans of FC "Nizhny Novgorod" are willing to spend their money to watch football. To make this happen, various measures have been developed to increase interactivity at the stadium. If the team is not yet ready to please the fans with good results, all conditions for a football feast should be created anyway.

\section{References}

Abrosimova, A. A., \& Kulikova, A. V. (2020). A study of PR technologies applied in sport. Sports management: current problems, practical experience and prospects. Collection of research papers (pp. 10-13). National Research Lobachevsky State University of Nizhny Novgorod.

Bagdatovich, D. A., Bagdatovich, E. N., Kambarovich, U. H., \& Ryskaliyev, S. (2017). Genesis of ideas marketing in the field of physical education and sport. Man In India, 97(2), 781-789.

Beech, J., \& Chadwick, S. (Eds.). (2010). Sports Marketing. (V. Bashkirova \& M. Chernoglazova, Trans.). Alpina Publishers. (Original work published 2007)

Government of the Nizhny Novgorod region. (2019, January 15). Gleb Nikitin approved the business plan for the operational activities of the stadium "Nizhny Novgorod" https:// government-nnov.ru/?id $=226710$

Kopyshov, A. (2013). Pass to football consumers. Kaleidoscope.

Kopyshov, A. (2015). Football marketing for the second league. Tutorial. Tyumen.

Lychagina, E. D., \& Angelova, O. Yu. (2019). The need to create an information Internet space for the development of sports movement in urban environment. Sports Management - 2019. Collection of abstracts and papers of the All-Russian scientific and practical conference with international participation (pp. 111-118). National Research Lobachevsky State University of Nizhny Novgorod

Myakonkov, V. B., Kopylova, T. V., \& Egorova, N. M. (2020). Sports marketing: textbook for universities (V. B. Myakonkov, Ed.). Yurayt.

Obozhina, D. A. (2017). Features of marketing in sports: Textbook. Publishing house of Ural University. https://elar.urfu.ru/bitstream/10995/54000/1/978-5-7996-2150-6_2017.pdf

Oiner, O. K. (2021). Marketing performance management: a textbook and a workshop for universities. Yurayt.

Prokhorenkova, I. A. (2017). Non profit sport marketing sphere. Education and science in the 21 $1^{\text {st }}$ century. Articles of the International Scientific and Practical Conference (pp. 144147). Vitebsk State Technological University 
Samatov, Ja. A. (2020). Model of preparation of future physical education teachers for sport marketing activities. Colloquium-journal, 27-1(79), 11-13.

Shteblov, I. N. (2015, August 17). How to feel part of the game while outside the stadium. http://www.sports.ru/tribuna/blogs/sportbizinfo/819602.html

Tarighi, R., Hamidi, M. (2017). The factors affecting development of marketing capability of collegiate sport. Annals of Applied Sport Science, 5(4), 6-75. https://doi. org/10.29252/aassjournal.5.4.67

Yesin, V. V. (2015). Sports marketing in football. Economy of Russia in the XXI century: collection of research papers of XII International Scientific and Practical Conference "Economic Sciences and Applied Research" (pp. 198-203). Publishing house of TPU. http://earchive. tpu.ru/handle/11683/15410 